\title{
Ultraviolet-absorbing compounds in the mucus of temperate Pacific tidepool sculpins: variation over local and geographic scales
}

\author{
Jill P. Zamzow* \\ Zoology Department and Hawaii Institute of Marine Biology, University of Hawaii, PO Box 1346, Kaneohe, Hawaii 96744, USA
}

\begin{abstract}
Temperate tidepool fishes of the family Cottidae (Teleostei) display biogeographic distribution patterns that vary with latitude and elevation within the intertidal zone. Middle and high intertidal pool species show a pattern of 'species replacement', with southern species being replaced by northern species at discrete locations along the coast. Lower intertidal pools, on the other hand, are dominated by a single species, Oligocottus snyderi, that occurs over an extremely wide latitudinal range. As a consequence of both latitudinal and elevational patterns, these fish experience variable amounts of ultraviolet (UV, 280 to $400 \mathrm{~nm}$ ) irradiation both between and within species. The mucus of tidepool sculpins was analyzed by absorbance spectrophotometry to compare concentrations of UV-absorbing compounds in the mucus of fish, with regard to geographic location or intertidal microhabitat. Mucus from northerly fishes absorbed significantly less UV than the mucus of southerly fishes. Overall, mucus from high intertidal pool fishes absorbed significantly more UV than mucus from middle or lower intertidal pool fishes, but differences were not detectable within a site. The mucus spectra of all fish surveyed contained a single UV absorption peak with maximum absorbance $\left(\lambda_{\max }\right)$ in the short-wavelength UVA (UVA $=320$ to $400 \mathrm{~nm}, \lambda_{\max }$ range $=323$ to $331 \mathrm{~nm}$ ). Compounds with $\lambda_{\max }$ in the UVB (280 to $320 \mathrm{~nm}$ ) or longer-wavelength UVA (ca. $360 \mathrm{~nm}$ ) were not found, although these compounds were present in 38 (UVB) and 59\% (longer UVA) of tropical species' mucus (138 species surveyed).
\end{abstract}

KEY WORDS: UV · Mycosporine-like amino acid $\cdot$ MAA $\cdot$ Mucus $\cdot$ Oligocottus $\cdot$ Clinocottus

Resale or republication not permitted without written consent of the publisher

\section{INTRODUCTION}

Sculpins (Cottidae: Teleostei) are an abundant and well-studied component of temperate Pacific tidepool communities (Morris 1962, Yoshiyama 1981, Yoshiyama et al. 1986, 1992). These fishes show speciesspecific distribution patterns, both vertically, within the intertidal zone, and along a latitudinal gradient. Within the intertidal zone, different species dominate high, mid-level, and low intertidal pools (Yoshiyama et al. 1986). The predominant fishes in high- and midintertidal pools show a latitudinal pattern of 'geographical replacement' by closely related and ecologically similar species (Morris 1962, Yoshiyama et al. 1986). South of San Francisco Bay, Clinocottus analis is the most common fish in high intertidal pools, whereas to the north, Oligocottus maculosus occupies this niche. Similarly, in mid-intertidal pools, the southerly C. recalvus is replaced by the northerly (and morphologically nearly identical) C. globiceps between San Francisco Bay and Monterey Bay. However, O. snyderi is the predominant low-intertidal species over a wide latitudinal range, from Alaska to Baja California (Eschmeyer et al. 1983).

Because of these variable distribution patterns, tidepool sculpins experience a wide range of incident ultraviolet radiation (UV, 280 to $400 \mathrm{~nm}$ ), both between and within species. By virtue of their shallow water environment, these fish experience potentially maximal incident UV (barring behavioral avoidance). The 
damaging effects of UV radiation, particularly shorter UVB (280 to $320 \mathrm{~nm}$ ) wavelengths, on fishes include cataracts, corneal damage, and epithelial 'sunburn' damage (Bullock 1982, Ahmed \& Setlow 1993, Cullen \& Monteith-McMaster 1993, Cullen et al. 1994). For fishes, sunburn can be fatal, but different fish species (and even strains within a species) are differentially tolerant of UV exposure (Blazer et al. 1997, Armstrong et al. 2002). The epithelial mucus of coral reef fishes ( $\mathrm{n}=138$ species) contains varying amounts of several 'sunscreen' compounds that absorb both UVB and UVA (320 to $400 \mathrm{~nm}$ ) radiation (Zamzow \& Losey 2002, J. P. Zamzow unpubl.). The UV-absorbing compounds of one species, Thalassoma duperrey, have been identified by high-performance liquid chromatography as the mycosporine-like amino acids (MAAs) palythine $\left(\lambda_{\max }[\right.$ maxiumum absorbance] $=320 \mathrm{~nm})$, palythinol $\left(\lambda_{\max }=332 \mathrm{~nm}\right)$, and asterina-330 $\left(\lambda_{\max }=330 \mathrm{~nm}, \mathrm{~J} . \mathrm{P}\right.$. Zamzow unpubl.). These compounds, along with palythene at $\lambda_{\max }=360 \mathrm{~nm}$, occur in the ocular tissues of coral reef fishes (Dunlap et al. 1989). The UVBabsorbing peak in coral reef fish mucus is presumed to arise from gadusol or deoxygadusol $\left(\lambda_{\max }=294\right.$ to 296 $\mathrm{nm}$ at $\mathrm{pH}>7$ ), compounds which occur in fish roe (Plack et al. 1981, Shick \& Dunlap 2002). The concentration of these sunscreens in the mucus changes according to the UV exposure of the fish (Zamzow \& Losey 2002), and they are sequestered from the diet (Mason et al. 1998, Zamzow in press).

The diets of Pacific tidepool fishes are well documented. Oligocottus snyderi feeds primarily on gammarid amphipods, as does O. maculosus (Grossman 1986). Clinocottus globiceps eats anemones and algae, whereas $C$. analis feeds on polychaetes and shrimp (Grossman 1986, Yoshiyama et al. 1996). Gammarid amphipods (Helbling et al. 2002), anemones (Banaszak \& Trench 1995), algae (Karsten et al. 1998), and shrimp (Grant et al. 1985) are known to possess MAAs, and these compounds are nearly ubiquitous in marine taxa (Shick \& Dunlap 2002).

Incident UV radiation varies widely with both latitude (Gleason et al. 1993, Madronich et al. 1998) and depth in the water column (Jerlov 1976). Additionally, due to the nature of the tidal cycle, fishes in high intertidal pools spend more time exposed to high UV levels than fishes in low intertidal pools (Ricketts et al. 1992). This study investigated whether the UV absorbance of the epithelial mucus of tidepool sculpins varied with latitude, vertical location within the intertidal zone, or both. I hypothesized that fishes from higher latitudes would possess less sunscreen in the mucus than fishes from lower latitudes, and that fish from higher tidepools would possess more sunscreen than those from lower tidepools.

\section{MATERIALS AND METHODS}

Fishes were collected with dip nets at low tide from 3 sites along the Pacific Coast of North America (Table 1). The sites were Soberanes Point, California $\left(36^{\circ} 27^{\prime} \mathrm{N}, 121^{\circ} 56^{\prime} \mathrm{W}\right.$; July 10 to 12,2002$)$; Arena Cove, California $\left(38^{\circ} 55^{\prime} \mathrm{N}, 123^{\circ} 43^{\prime} \mathrm{W}\right.$; July 23 to 25,2002$)$; and Sitka, Alaska $\left(57^{\circ} 02^{\prime} \mathrm{N}, 135^{\circ} 21^{\prime} \mathrm{W}\right.$; August 7 to 11 , 2002). The first 2 sites were chosen from Yoshiyama (1986), and were expected to represent the southern species complex, and an overlap zone between southern and northern species, respectively. The third site was chosen from Eschmeyer (1983) as the extreme northern range of Oligocottus snyderi, and was expected to elucidate any subtle changes that might occur with latitude, as well as representing the northern species complex. Sites were sampled beginning in the south, in order to bias the results against any possible cumulative effect of summertime UV exposure. The Arena Cove site was expected to be a zone of overlap for direct comparison of the mucus of Clinocottus analis and O. maculosus (Yoshiyama et al. 1986); however, no $C$. analis were present at the time of sampling (approximately 25 work-hours of search time).

The relative height of tidepools within the intertidal zone was characterized as low, mid, or high, modified from Yoshiyama (1981). For this study, mid-intertidal pools were defined as Yoshiyama's 'high-offshore' and 'high-intermediate' pool categories, whereas high intertidal pools were his 'high-nearshore' pool category (Yoshiyama 1981). All 3 sites consisted of waveexposed rocky benches, and the types of tidepools present were quite similar. Low-intertidal pools were of

Table 1. Cottid species used in general linear model of integrated UV absorbance (see also Fig. 2)

\begin{tabular}{|c|c|c|c|c|}
\hline Site (Latitude) & Date (2002) & Zone & Species & $\mathrm{n}$ \\
\hline $\begin{array}{l}\text { Soberanes Point } \\
\left(36^{\circ} 27^{\prime} \mathrm{N}, 121^{\circ} 56^{\prime} \mathrm{W}\right)\end{array}$ & Jul 10-12 & $\begin{array}{l}\text { High } \\
\text { Mid } \\
\text { Low }\end{array}$ & $\begin{array}{l}\text { Clinocottus analis } \\
\text { Clinocottus recalvus } \\
\text { Oligocottus snyderi }\end{array}$ & $\begin{array}{r}8 \\
10 \\
9\end{array}$ \\
\hline $\begin{array}{l}\text { Arena Cove } \\
\left(38^{\circ} 55^{\prime} \mathrm{N}, 123^{\circ} 43^{\prime} \mathrm{W}\right)\end{array}$ & Jul 23-25 & $\begin{array}{l}\text { High } \\
\text { Mid } \\
\text { Low }\end{array}$ & $\begin{array}{l}\text { Oligocottus maculosus } \\
\text { Clinocottus globiceps } \\
\text { Oligocottus snyderi }\end{array}$ & $\begin{array}{l}10 \\
10 \\
11\end{array}$ \\
\hline $\begin{array}{l}\text { Sitka } \\
\left(57^{\circ} 02^{\prime} \mathrm{N}, 135^{\circ} 21^{\prime} \mathrm{W}\right)\end{array}$ & Aug 7-11 & $\begin{array}{l}\text { High } \\
\text { Mid } \\
\text { Low }\end{array}$ & $\begin{array}{l}\text { Oligocottus maculosus } \\
\text { Clinocottus globiceps } \\
\text { Clinocottus embryum } \\
\text { Oligocottus snyderi }\end{array}$ & $\begin{array}{r}10 \\
2 \\
5 \\
8\end{array}$ \\
\hline
\end{tabular}


moderate depths ( 0.25 to $1.5 \mathrm{~m}$ ) and contained the most macroalgal cover, mid tidepools were generally deep $(\sim 0.75$ to $1.5 \mathrm{~m})$ potholes or gorges with less macroalgal cover than low pools, and high tidepools had large surface-area-to-volume ratios $(<1 \mathrm{~m}$ depths and 1 to $3 \mathrm{~m}$ across) and the least amount of macroalgal cover.

Fishes were held in buckets of aerated seawater prior to sampling for no more than $3 \mathrm{~h}$ post-capture. One fish of each species was euthanized, and transmission of the ocular media was determined following Losey et al. (2000). After sampling, fishes were returned to their home tidepools, and any subsequent collections took place at least $100 \mathrm{~m}$ distant.

Spectrophotometric methods followed Zamzow \& Losey (2002). Briefly, a mucus sample was taken from the dorsal flank of each fish and 'squashed' to a standard depth of $0.25 \mathrm{~mm}$ between $2 \mathrm{UV}$-transparent microscope slides, with coverslips at either end to act as spacers (Zamzow \& Losey 2002). While mucus of the fishes in this study was not examined, microscopic examination of mucus samples from Hawaiian fishes did not indicate the presence of epithelial cells (J. P. Zamzow unpubl.). Absorbance of each sample was measured from 280 to $400 \mathrm{~nm}$ with a fiber-optic spectrophotometer (Fig. 1). For the purposes of data analysis, the variable 'integrated absorbance' was used. Integrated absorbance consists of the sum of the absorbance values (units = optical density [OD]) at each wavelength integer from 280 to $400 \mathrm{~nm}$.

General linear model (GLM) analysis was performed with SAS systems, Release 8.02. The initial GLM tested the effects of geographic site, relative intertidal elevation, standard length, species of fish, and interaction terms, on integrated absorbance. Non-significant independent variables $(p>0.5)$ were sequentially excluded, and the explanatory variables in the final model were geographic site, intertidal elevation, and their interaction. A second GLM tested for effects of site and location (and their interaction) on the $\lambda_{\max }$ of the fishes' mucus.

\section{RESULTS}

The mucus of both Oligocottus spp. and Clinocottus spp. absorbed UV, with the main absorbance peak located at ca. $330 \mathrm{~nm}$. This is unlike the mucus of tropical fishes that often contains either a UVB-absorbing peak at ca. $294 \mathrm{~nm}$ (38\% of 138 species from 25 families, J. P. Zamzow unpubl.), or evidence of longerwavelength $\left(\lambda_{\max } \approx 360 \mathrm{~nm}\right)$ absorbing compounds (59\% of 138 species). The mucus absorbance spectrum of a phylogenetically unrelated, but ecologically similar, high intertidal-zone fish, Istiblennius lineatus (family Bleniidae), from Majuro Atoll $\left(7^{\circ} 09^{\prime} \mathrm{N}, 171^{\circ} 12^{\prime} \mathrm{E}\right.$, June 13, 2001), is shown for purposes of comparison (Fig. 1a).

Integrated absorbance showed significant effects of both site and relative height within the intertidal zone (Table 2, Fig. 2, ANOVA: Site $F_{2,70}=46.44, \mathrm{p}<0.0001$; Height $\left.F_{2,70}=9.41, \mathrm{p}<0.001\right)$. Fishes from high intertidal pools had significantly greater UV absorbance than those from low- or mid-intertidal pools (least square means [LSM] comparison, Tukey post-hoc adjustment, Mid: $\mathrm{p}<0.001$, Low: $\mathrm{p}<0.01$ ), but the mucus of low- and mid-intertidal pool fish could not be distinguished from one another (LSM, Tukey, $\mathrm{p}=0.94$ ). Overall, fish from Soberanes Point had significantly higher mucus absorbance than fish from Arena Cove (LSM, Tukey, $\mathrm{p}=0.02$ ) or Sitka (LSM, Tukey, $\mathrm{p}<$ 0.0001), and fish from Arena Cove had significantly higher integrated UV absorbance than fish from Sitka (LSM, Tukey, $\mathrm{p}<0.0001$ ). There was no interaction between relative height and geographic location.

The $\lambda_{\max }$ of fishes' mucus varied significantly by intertidal height but not by location (ANOVA: Height

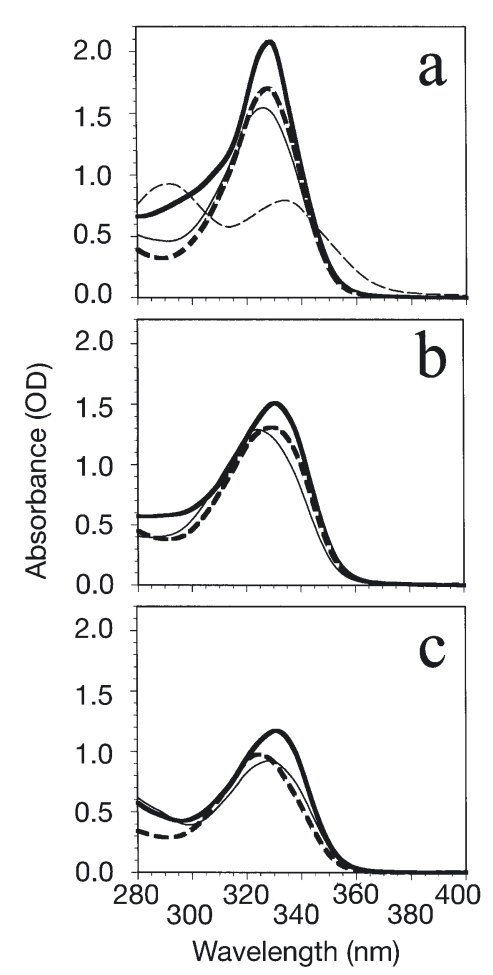

Fig. 1. Representative absorbance spectra of temperate Pacific cottid mucus. Heavy solid lines: high-tidepool species; heavy dashed lines: mid-tidepool species; thin lines: low-tidepool species (Oligocottus snyderi in all panels). (a) Soberanes Point. High species: Clinocottus analis; mid species: C. recalvus. Istiblennius lineatus, a tropical blenniid high tidepool species from Majuro Atoll, is shown for comparison (thin dashed line). (b) Arena Cove. High species: O. maculosus; mid species: C. globiceps. (c) Sitka. Species sampled as in (b) 
Table 2. Post-hoc comparison p-values, Tukey corrected, for the 2-way ANOVA of integrated absorbance by site and intertidal height. Sites: $\mathrm{SP}=$ Soberanes Point, $\mathrm{AC}=$ Arena Cove, $\mathrm{S}=$ Sitka; HI = high-, $\mathrm{MID}=$ mid-, and LO = low-intertidal pools $($ see 'Materials and methods' for details)

\begin{tabular}{|lccccccc|}
\hline Site & S HI & S MID & S LO & AC HI & AC MID & AC LO & SP HI \\
\hline SP LOW & 0.002 & 0.002 & 0.0002 & 0.992 & 0.707 & 0.852 & 0.212 \\
SP MID & 0.014 & 0.014 & 0.001 & 0.836 & 0.935 & 0.993 & 0.021 \\
SP HI & $<0.0001$ & $<0.0001$ & $<0.0001$ & 0.637 & 0.0004 & 0.003 & \\
AC LOW & 0.093 & 0.061 & 0.012 & 0.227 & 1.00 & & \\
AC MID & 0.244 & 0.173 & 0.039 & 0.138 & & & \\
AC HI & $<0.0001$ & 0.0001 & $<0.0001$ & & & & \\
S LOW & 0.99 & 1.00 & & & & & \\
S MID & 0.99 & & & & & & \\
\end{tabular}

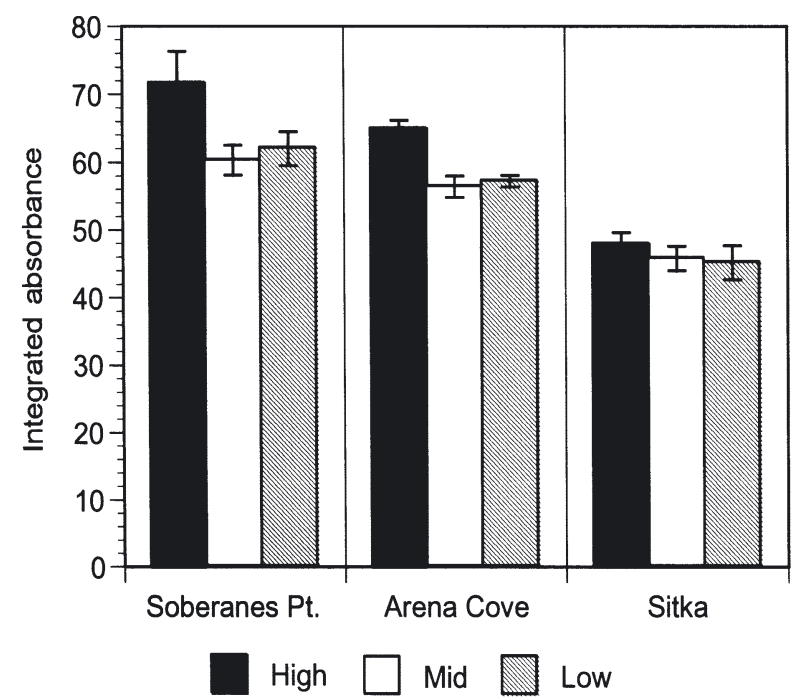

Fig. 2. Integrated absorbance for Clinocottus and Oligocottus species from high-, mid-, and low-intertidal pools at each site $($ mean $\pm \mathrm{SE})$. Low-tidepool data for all 3 sites are from $O$. snyderi mucus. Species sampled: Soberanes Point, C. analis (high tidepools) and $C$. recalvus (mid tidepools); Arena Cove, $O$. maculosus (high tidepools) and C. globiceps (mid tidepools); Sitka, O. maculosus (high tidepools) and C. globiceps and $C$. embryum (mid tidepools). See Table 2 for post-hoc pair-wise comparisons
(Table 3). Among the cottids, Artedius spp. mucus had integrated absorbance values similar to those found for Oligocottus and Clinocottus species, whereas the mucus of Enophrys bison demonstrated little UV absorbance.

The ocular media of all species surveyed blocked UV radiation from reaching the retina; the wavelength of $50 \%$ transmission $\left(\mathrm{T}_{50}\right)$ of the lens for each species was $399 \mathrm{~nm}$ or higher (Table 4). For Artedius lateralis, Clinocottus globiceps and Oligocottus snyderi, corneal absorbance resulted in higher $\mathrm{T}_{50}$ values for whole-eye transmission.

\section{DISCUSSION}

The UV absorbance of Oligocottus and Clinocottus species mucus was clearly reflective of their habitat, both along a latitudinal gradient and within the intertidal zone. Overall, fishes from high-intertidal pools had more sunscreen in the mucus than those from midor low-intertidal pools, though differences were not detectable within a site (Table 2). Fish in highintertidal pools experienced more potentially damaging UV radiation than those in low-intertidal pools,
$F_{2,70}=35.44, \mathrm{p}<0.0001 ;$ Site $F_{2,70}=0.2$, $\mathrm{p}=0.8)$. However, a significant interaction between height and location $\left(\right.$ ANOVA: Height $\times$ Site $F_{4,70}=12.96$, $\mathrm{p}<0.001)$ reflects the fact that the height effect varied depending on the site, and therefore no clear trend was evident in terms of either height or location.

Additional intertidal species were opportunistically surveyed for mucus transmission, and the non-cottids had very low integrated absorbance values
Table 3. Additional temperate tidepool species sampled for mucus and ocular media

\begin{tabular}{|llcc|}
\hline Site & \multicolumn{1}{c}{ Species (family) } & $\begin{array}{c}\text { Integrated } \\
\text { absorbance } \\
\text { (mean } \pm \text { SE) }\end{array}$ & $\mathrm{n}$ \\
\hline Soberanes Point & Cebidichthys violaceus (Stichaeidae) & 11.1 & 1 \\
& Gobiesox maeandricus (Gobiesocidae) & 25.5 & 1 \\
Arena Cove & Xererpes fucorum (Pholidae) & 10.9 & 1 \\
Sitka & Artedius lateralis (Cottidae) & $51.1 \pm 0.9$ & 2 \\
& Artedius harringtoni (Cottidae) & 35.5 & 1 \\
& Artedius lateralis (Cottidae) & $40.7 \pm 1.8$ & 8 \\
& Enophrys bison (Cottidae) & $15.4 \pm 1.2$ & 3 \\
\hline
\end{tabular}


Table 4. Cottid species sampled for ocular media transmission. $\mathrm{T}_{50}$ : wavelength of $50 \%$ transmission. For Artedius lateralis, Clinocottus globiceps and Oligocottus snyderi, corneal absorbance resulted in higher $\mathrm{T}_{50}$ values for whole eye transmission

\begin{tabular}{|llc|}
\hline Species & \multicolumn{1}{c|}{ Site } & Lens $\mathrm{T}_{50}(\mathrm{~nm})$ \\
\hline Artedius lateralis & Sitka & 410 \\
Clinocottus analis & Soberanes Point & 409 \\
C. globiceps & Arena Cove & 412 \\
C. recalvus & Soberanes Point & 412 \\
Cebidichthys violaceus & Soberanes Point & 407 \\
Enophrys bison & Sitka & 402 \\
Oligocottus maculosus & Arena Cove & 408 \\
O. snyderi & Soberanes Point & 399 \\
\hline
\end{tabular}

both due to increased tidal exposure and because high pools were shallow with sparse macroalgal cover. High-tidepool fish may mitigate their exposure to this radiation through increased mucus absorbance. Both $O$. maculosus and $C$. analis commonly occur in open sandy areas of large high tidepools, whereas $O$. snyderi shows a preference for plant cover in low tidepools (Nakamura 1976, pers. obs.). These behavioral differences may contribute to the differences found in mucus absorbance between the species.

Fishes from lower latitudes experience higher levels of UV radiation than species from higher latitudes (Gleason et al. 1993, Madronich et al. 1998). In the 2 wk prior to sampling, the average integrated UV irradiance (erythmally weighted) at each site was as follows (mean $\pm \mathrm{SE}$ ): Soberanes Point, $5571 \pm 193 \mathrm{~J} \mathrm{~m}^{-2}$; Arena Cove, $4936 \pm 237 \mathrm{~J} \mathrm{~m}^{-2}$; Sitka, $2264 \pm 120 \mathrm{~J} \mathrm{~m}^{-2}$ (total ozone mapping spectrometer [TOMS] UV data, available at http://toms.gsfc.nasa.gov/ery_uv/euv.html). The irradiance at each site was significantly different from the next (1-way ANOVA, $F_{2,41}=95.9, \mathrm{p}<0.0001$; Tukey post-hoc, Soberanes vs Arena Cove $\mathrm{p}=0.04$, Arena Cove vs Sitka $\mathrm{p}<0.0001)$. Similarly, the overall integrated UV absorbance of tidepool fish mucus increased significantly from one site to the next. Soberanes Point tidepool fishes, exposed to 2.5 times the weighted irradiance of Sitka tidepool fishes, had approximately 1.5 times higher integrated mucus absorbance, which may protect them from increased UV levels.

Another possible factor influencing the UV absorbance of fish mucus is temperature. Both seawater temperature and UV radiation fluctuations significantly affect MAA tissue concentrations in soft coral colonies (Michalek-Wagner 2001). Temperature, which varies in the same manner as UV irradiance over latitude and intertidal height, may also play a role in the UV absorbance patterns found in this study. However, as temperature is generally tightly correlated with UV irradiance, experimental manipulations would be necessary to determine the role of each environmental factor.

UV-absorbing compounds in the mucus and ocular media of fishes are derived from the diet (Mason et al. 1998, Zamzow in press). Judging from the ocular media transmission values (Table 4), as well as the mucus absorbance spectra (Fig. 1), all of the Clinocottus and Oligocottus species surveyed were capable of sequestering UV-absorbing compounds from their diet. However, the compounds sequestered in the ocular tissues clearly differ from those found in the mucus. The fact that these UV-absorbing compounds are accumulated up the food web suggests that they are ecologically important in terms of sunscreen protection.

Intertidal fishes do not seem to be simply passively excreting all available dietary compounds in their mucus. Oligocottus maculosus, O. snyderi, and Xererpes fucorum consume primarily gammarid amphipods (Grossman 1986). However, in contrast to the 2 Oligocottus species, $X$. fucorum showed almost no sunscreen in the mucus. This may be due to phylogenetic differences in the ability to sequester UV-absorbing compounds in the mucus, but high mucus absorbance did not occur in all cottids (see Enophrys bison, Table 3). X. fucorum is generally found under rocks or in crevices (Eschmeyer et al. 1983), and thus may behaviorally regulate its UV exposure, precluding the need for high mucus absorbance. Cebidicthys violaceus (a herbivore) and Gobiesox maeandricus (an invertebrate predator) often shelter under rocks and algae (Yoshiyama 1981, Martin \& Bridges 1999), and these species also had low levels of sunscreen in the mucus (Table 3). The dietary source of MAAs for these species may vary due to bathymetric or latitudinal patterns in MAA concentrations in prey items (Karsten et al. 1998, Hoyer et al. 2001), and this may also contribute to the observed patterns of absorbance.

UV absorbance of the mucus varies not only between species, but also within species as a function of latitude, where individuals from higher latitude sites have significantly less sunscreen in the mucus than those from lower latitudes. It is likely that the dietary availability of MAAs varies over a latitudinal gradient (Karsten et al. 1998). However, the aforementioned differences in mucus absorbance between tidepool species with similar diets (and particularly the lack of compounds in Xererpes fucorum mucus) suggest that differential sequestration or secretion of MAAs, as well as differential dietary availability, may result in the latitudinal patterns found in this study. Experiments with coral reef fish have shown that fish fed an identical diet rich in MAAs sequester compounds in the mucus only in response to UV exposure (Zamzow in press). A study on the ovaries of sea urchins, however, found no UV 
exposure effect on MAA sequestration (Adams et al. 2001), so this ability to acclimate is clearly not universal across taxa.

The lack of UVB- and longer-wavelength UVAabsorbing compounds in the mucus of temperate tidepool fishes is noteworthy. Thirty-eight percent of tropical fishes (138 species surveyed from 25 families) have compounds in their mucus with $\lambda_{\max }$ in the UVB range (J. P. Zamzow unpubl.). Whether the absence of these compounds in the mucus of temperate fishes is due to dietary limitations, or phylogenetic differences in sequestration ability, is unknown. Furthermore, there is no evidence for the secretion of longer-wavelength UVA compounds, such as palythene $\left(\lambda_{\max }=360 \mathrm{~nm}\right)$, into the mucus of temperate tidepool fishes, as has been found in many tropical species $(59 \%$ of 138 species showed evidence of a compound with $\lambda_{\max }=$ $360 \mathrm{~nm}$, J. P. Zamzow unpubl.). The ocular media data (Table 4) demonstrate that temperate tidepool fishes are able to sequester longer wavelength UVA-absorbing compounds, and therefore these compounds must be available in the diet.

It is impossible to say with the data presented here whether the observed patterns of variability in mucus absorbance of different species is simply acclimatization to their habitat, or whether the ability to sequester large amounts of sunscreen may be a limiting factor determining the geographic distribution of sister species. Experimental manipulations might help to elucidate this question. Nonetheless, it does seem that tidepool sculpins are able to acclimatize to their UV environment, on both local and geographic scales.

Acknowledgements. I am grateful to R. Yoshiyama and G. Cailliet for sharing details of their intertidal collection sites; W. Loeffler, P. FitzGibbon, and D. Copson for aid in field collections; and H. Zamzow, A. Zamzow and G. Losey for providing necessary field equipment and support. The manuscript was greatly improved by editorial comments provided by P. Nelson, P. Nachtigall, G. Losey, M. Shick, and 2 anonymous reviewers. Funding was provided by the University of Hawaii Arts and Sciences Advisory Council and Sigma Xi GIAR. Contribution Number 1165 of the Hawaii Institute of Marine Biology.

\section{LITERATURE CITED}

Adams NL, Shick JM, Dunlap WC (2001) Selective accumulation of mycosporine-like amino acids in ovaries of the green sea urchin, Strongylocentrotus droebachiensis, is not affected by ultraviolet radiation. Mar Biol 138:267-280

Ahmed FE, Setlow RB (1993) Ultraviolet radiation-induced DNA damage and its photorepair in the skin of the platyfish Xiphophorus. Cancer Res 53:2249-2255

Armstrong TN, Reimschuessel R, Bradley BP (2002) DNA damage, histological changes and DNA repair in larval Japanese medaka (Oryzias latipes) exposed to ultraviolet$\mathrm{B}$ radiation. Aquat Toxicol 58:1-14
Banaszak AT, Trench RK (1995) Effects of ultraviolet (UV) radiation on marine microalgal-invertebrate symbioses. II. The synthesis of mycosporine-like amino acids in response to exposure to UV in Anthopleura elegantissima and Cassiopeia xamachana. J Exp Mar Biol Ecol 194: $233-250$

Blazer VS, Fabacher DL, Little EE, Ewing MS, Kocan KM (1997) Effects of ultraviolet-B radiation on fish: histologic comparison of a UVB-sensitive and a UVB-tolerant species. J Aquat Anim Health 9:132-143

Bullock AM (1982) The pathological effects of ultraviolet radiation on the epidermis of teleost fish with reference to the solar radiation effect in higher animals. Proc R Soc Edinb B 81:199-210

Cullen AP, Monteith-McMaster CA (1993) Damage to the rainbow trout (Oncorhynchus mykiss) lens following an acute dose of UVB. Curr Eye Res 12:97-106

Cullen AP, Monteith-McMaster CA, Sivak JG (1994) Lenticular changes in rainbow trout following chronic exposure to UV radiation. Curr Eye Res 13:731-737

Dunlap WC, Williams DM, Chalker BE, Banaszak AT (1989) Biochemical photoadaptation in vision: UV-absorbing pigments in fish eye tissues. Comp Biochem Physiol B 93: 601-607

Eschmeyer WN, Herald ES, Hammann H (1983) A field guide to Pacific coast fishes of North America. Houghton Mifflin Company, Boston

Gleason JF, Bhartia PK, Herman JR, McPeters R and 10 others (1993) Record low global ozone in 1992. Science 260: 523-526

Grant PT, Middleton C, Plack PA, Thomson RH (1985) The isolation of four aminocyclohexenimines (mycosporines) and a structurally related derivative of cyclohexane-1:3dione (gadusol) from the brine shrimp, Artemia. Comp Biochem Physiol B 80:755-759

Grossman GD (1986) Food resource partitioning in a rocky intertidal fish assemblage. J Zool Soc Lond B 1:317-355

Helbling EW, Fernando Menchi C, Villafane VE (2002) Bioaccumulation and role of UV-absorbing compounds in two marine crustacean species from Patagonia, Argentina. Photochem Photobiol Sci 1:820-825

Hoyer K, Karsten U, Sawall T, Wiencke C (2001) Photoprotective substances in Antarctic macroalgae and their variation with respect to depth distribution, different tissues and developmental stages. Mar Ecol Prog Ser 211:117-129

Jerlov NG (1976) Marine optics. Elsevier Scientific Publishing Company, Amsterdam

Karsten U, Sawall T, Hanelt D, Bischof K, Figueroa FL, FloresMoya A, Wiencke C (1998) An inventory of UV-absorbing mycosporine-like amino acids in macroalgae from polar to warm-temperate regions. Bot Mar 41:443-453

Losey GS, Nelson PA, Zamzow JP (2000) Ontogeny of spectral transmission in the eye of the tropical damselfish, Dascyllus albisella (Pomacentridae), and possible effects on UV vision. Environ Biol Fishes 59:21-28

Madronich S, McKenzie RL, Bjorn LO, Caldwell MM (1998) Changes in biologically active ultraviolet radiation reaching the Earth's surface. J Photochem Photobiol B 46:5-19

Martin KLM, Bridges CR (1999) Respiration in water and air. In: Horn MH, Martin KLM, Chotkowski MA (eds) Intertidal fishes: life in two worlds. Academic Press, San Diego

Mason DS, Schafer F, Shick JM, Dunlap WC (1998) Ultraviolet radiation-absorbing mycosporine-like amino acids (MAAS) are acquired from their diet by medaka fish (Oryzias latipes) but not by SKH-1 hairless mice. Comp Biochem Physiol A 120:587-598

Michalek-Wagner K (2001) Seasonal and sex-specific varia- 
tions in levels of photo-protecting mycosporine-like amino acids (MAAs) in soft corals. Mar Biol 139:651-660

Morris RW (1962) Distribution and temperature sensitivity of some eastern Pacific cottid fishes. Physiol Zool 34:217-227

Nakamura R (1976) Experimental assessment of factors influencing microhabitat selection by the two tidepool fishes Oligocottus maculosus and O. snyderi. Mar Biol 37:97-104

Plack PA, Fraser NW, Grant PT, Middleton C, Mitchell AI, Thomson RH (1981) Gadusol, an enolic derivative of cyclohexane-1,3-dione present in the roes of cod and other marine fish. Biochem J 199:741-747

Ricketts EF, Calvin J, Hedgpeth JW, Phillips DW (1992) Between Pacific tides. Stanford University Press, Stanford, CA

Shick JM, Dunlap WC (2002) Mycosporine-like amino acids and related gadusols: Biosynthesis, accumulation, and UV-protective functions in aquatic organisms. Annu Rev Physiol 64:223-262

Yoshiyama RM (1981) Distribution and abundance patterns of

Editorial responsibility: Howard Browman (Contributing Editor), Storebø, Norway rocky intertidal fishes in central California. Environ Biol Fishes 6:315-332

Yoshiyama RM, Sassaman C, Lea RN (1986) Rocky intertidal fish communities of California: temporal and spatial variation. Environ Biol Fishes 17:23-40

Yoshiyama RM, Gaylord KB, Philippart MT, Moore TR and 5 others (1992) Homing behavior and site fidelity in intertidal sculpins. J Exp Mar Biol Ecol 160:115-130

Yoshiyama RM, Wallace RD, Burns JL, Knowlton AL, Welter JR (1996) Laboratory food choice by the mosshead sculpin, Clinocottus globiceps (Girard) (Teleostei; Cottidae), a predator of sea anemones. J Exp Mar Biol Ecol 204:23-42

Zamzow JP (in press) Effects of diet, ultraviolet exposure and gender on the ultraviolet absorbance of fish mucus and ocular media. Mar Biol

Zamzow JP, Losey GS (2002) Ultraviolet radiation absorbance by coral reef fish mucus: photo-protection and visual communication. Environ Biol Fishes 63:41-47

Submitted: April 15, 2003; Accepted: August 28, 2003

Proofs received from author(s): November 5, 2003 